\title{
Disturbed $\mathrm{Ca}^{2+}$ Homeostasis Increases Glutaminyl Cyclase Expression; Connecting Two Early Pathogenic Events in Alzheimer's Disease In Vitro
}

\author{
Line De Kimpe ${ }^{1}$, Anna Bennis ${ }^{1}$, Rob Zwart ${ }^{1}$, Elise S. van Haastert ${ }^{3}$, Jeroen J. M. Hoozemans ${ }^{3}$, \\ Wiep Scheper ${ }^{1,2 *}$
}

1 Department of Genome Analysis, Academic Medical Center/University of Amsterdam, Amsterdam, The Netherlands, 2 Department of Neurology, Academic Medical Center/University of Amsterdam, Amsterdam, The Netherlands, 3 Department of Pathology, VU University Medical Center, Amsterdam, The Netherlands

\begin{abstract}
A major neuropathological hallmark of Alzheimer's disease (AD) is the deposition of aggregated $\beta$ amyloid $(A \beta)$ peptide in the senile plaques. $A \beta$ is a peptide of $38-43$ amino acids and its accumulation and aggregation plays a key role early in the disease. A large fraction of $\beta$ amyloid is $\mathrm{N}$-terminally truncated rendering a glutamine that can subsequently be cyclized into pyroglutamate $(\mathrm{pE})$. This makes the peptide more resistant to proteases, more prone to aggregation and increases its neurotoxicity. The enzyme glutaminyl cyclase (QC) catalyzes this conversion of glutamine to $\mathrm{pE}$. In brains of AD patients, the expression of QC is increased in the earliest stages of pathology, which may be an important event in the pathogenesis. In this study we aimed to investigate the regulatory mechanism underlying the upregulation of QC expression in AD. Using differentiated SK-N-SH as a neuronal cell model, we found that neither the presence of A $\beta$ peptides nor the unfolded protein response, two early events in $A D$, leads to increased $Q C$ levels. In contrast, we demonstrated increased QC mRNA levels and enzyme activity in response to another pathogenic factor in $A D$, perturbed intracellular $\mathrm{Ca}^{2+}$ homeostasis. The $\mathrm{QC}$ promoter contains a putative binding site for the $\mathrm{Ca}^{2+}$ dependent transcription factors c-fos and c-jun. C-fos and c-jun are induced by the same $\mathrm{Ca}^{2+}$-related stimuli as QC and their upregulation precedes QC expression. We show that in the human brain QC is predominantly expressed by neurons. Interestingly, the $\mathrm{Ca}^{2+}$ - dependent regulation of both c-fos and QC is not observed in non-neuronal cells. Our results indicate that perturbed $\mathrm{Ca}^{2+}$ homeostasis results in upregulation of $\mathrm{QC}$ selectively in neuronal cells via $\mathrm{Ca}^{2+}$ - dependent transcription factors. This suggests that disruption of $\mathrm{Ca}^{2+}$ homeostasis may contribute to the formation of the neurotoxic $p E A \beta$ peptides in Alzheimer's disease.
\end{abstract}

Citation: De Kimpe L, Bennis A, Zwart R, van Haastert ES, Hoozemans JJM, et al. (2012) Disturbed Ca ${ }^{2+}$ Homeostasis Increases Glutaminyl Cyclase Expression; Connecting Two Early Pathogenic Events in Alzheimer's Disease In Vitro. PLoS ONE 7(9): e44674. doi:10.1371/journal.pone.0044674

Editor: Koichi M. lijima, Thomas Jefferson University, United States of Amercia

Received May 10, 2012; Accepted August 10, 2012; Published September 7, 2012

Copyright: (c) 2012 De Kimpe et al. This is an open-access article distributed under the terms of the Creative Commons Attribution License, which permits unrestricted use, distribution, and reproduction in any medium, provided the original author and source are credited.

Funding: This study was supported by the European Commission as part of the 6th Framework Program (EDAR, contract \# 37670) and the 7th Framework program (NAD, grant agreement \# 212043), Internationale Stichting Alzheimer Onderzoek Nederland (ISAO \#07506) and the Netherlands Organisation for Scientific Research (NWO; Meervoud Grant \#836.05.060). The funders had no role in study design, data collection and analysis, decision to publish, or preparation of the manuscript.

Competing Interests: The authors have declared that no competing interests exist.

* E-mail: w.scheper@amc.uva.nl

\section{Introduction}

The formation of $\mathrm{A} \beta$ peptides from the amyloid precursor protein (APP) is a crucial event in Alzheimer's disease (AD). Proteolytic processing of APP results in different forms of the A $\beta$ protein with different characteristics [1]. C-terminal cleavage of the $A \beta$ sequence by $\gamma$-secretase leads to the formation of $A \beta 1-x$ varying in length from 38-43 amino acids. In addition, N-terminal truncations have been identified that expose a glutamic acid at position 3 or 11 . This glutamate residue can be cyclized into a pyroglutamate $(\mathrm{pE}) \mathrm{N}$-terminus which leads to the formation of $\mathrm{A} \beta_{3(\mathrm{pE})-\mathrm{x}}$ and $\mathrm{A} \beta_{11(\mathrm{pE})-\mathrm{x}}$ in a reaction catalyzed by glutaminyl cyclases (QCs). The pE residue stabilizes the peptide by protection against degradation by aminopeptidases [2] and lysosomal proteases [3]. In addition, the conversion of the glutamatic acid into a $\mathrm{pE}$ residue results in a loss of charge and the consequent increased hydrophobicity leads to an increase in aggregation propensity $[4,5]$. It has been suggested that $\mathrm{pE} \mathrm{A} \beta$ provides a seed for the $A \beta$ aggregation process [6]. The change in physicochem- ical properties is accompanied by increased neurotoxicity of $\mathrm{pE} A \beta$ peptides compared to unmodified $A \beta$ species [6-8].

QC is abundantly expressed in the cortex and hippocampus and its expression correlates with the appearance of $\mathrm{pE} \mathrm{A} \beta[9,10]$. In a transgenic $\mathrm{AD}$ mouse model, overexpression of human QC results in an increase in $A \beta_{3(\mathrm{pE})-42}$ peptides, plaque formation as well as memory impairments [11]. Moreover, the formation of the neurotoxic $\mathrm{pE} A \beta$ peptides can be prevented by inhibition of $\mathrm{QC}$ in vitro and in vivo $[10,12]$. Oral application of a QC inhibitor diminishes plaque formation and improves performance in spatial learning tests and context memory in two transgenic mouse models of AD [12]. QC expression is upregulated at the mRNA and protein level in the $\mathrm{AD}$ brain [12], which may be an important pathogenic factor triggered early in the development of AD pathogenesis.

Accumulation of $\mathrm{A} \beta$ is an early pathogenic event in $\mathrm{AD}$. In particular, oligomeric assemblies of $\mathrm{A} \beta$ interfere with cellular physiology. $\mathrm{AD}$ is a multifactorial disease, and additional dysfunction that is not directly related to $A \beta$ may converge with 
the toxic effects of $\mathrm{A} \beta$. For example, our lab has previously shown that the unfolded protein response (UPR) is activated early in AD $[13,14]$. The UPR is a stress response of the endoplasmic reticulum (ER) that is activated in response to disturbed ER homeostasis. Several homeostatic and biosynthetic pathways are located in the ER: it is a site for $\mathrm{Ca}^{2+}$ homeostasis, redox balance, lipid synthesis and the synthesis and folding of membrane bound and secretory proteins. We showed that increased production of $A \beta$ [15], as well as the presence of early oligomeric $A \beta$ aggregates [16] sensitize cells for UPR induction and ER stress toxicity, indicating an interaction between these two early events in AD pathology. Recently our group demonstrated that the accumulation of $\mathrm{pE} A \beta$ aggregates in human cortex is highly dependent on the presence of AD pathology, but also on age [3]. Also changes in $\mathrm{Ca}^{2+}$ homeostasis that have been suggested to be involved early in AD pathology are highly age related [17-20]. The above illustrates that multiple factors can affect $\mathrm{AD}$ pathogenesis. In this study we investigated whether these key early pathogenic events -A $\beta$, UPR activation and perturbed $\mathrm{Ca}^{2+}$ homeostasis - affect QC expression.

\section{Results}

\section{Upregulation of QC mRNA is a very Early Event in AD Pathology}

Elaborating on the previously reported QC mRNA expression data in the neocortex of $\mathrm{AD}$ patients [12], we determined the expression of QC mRNA in the hippocampus/entorhinal cortex of a cohort of age-matched patients with varying stages of $\mathrm{AD}$ pathology. We observe a significant increase in mRNA levels of QC in the patients with the earliest stages of pathology (Fig. 1). Levels are the highest in low Braak scores for tau pathology (1-3) with many amyloid deposits in the hippocampus. In patients with more advanced tau pathology the QC levels are lower, in accordance with the observations in the cortex in the previous study. This indicates that $\mathrm{QC}$ is upregulated in the earliest stages of $\mathrm{AD}$ pathology.

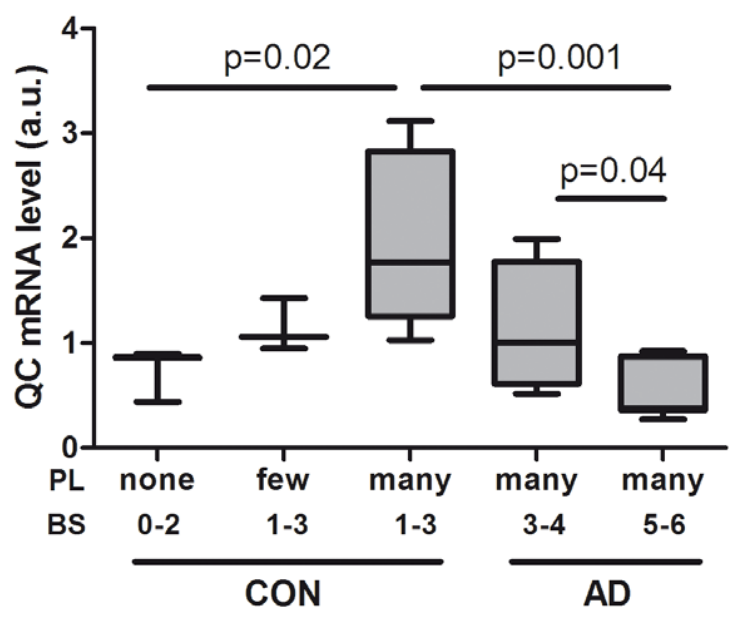

Figure 1. QC mRNA expression is increased in earliest stages of AD pathology. Expression of QC mRNA was determined in a cohort of patients with varying stages of $A D$ pathology (see materials and methods for details). CON and AD refer to the clinical diagnosis, BS is Braak score for tau pathology, $\mathrm{PL}$ is the plaqueload in the hippocampus/entorhinal cortex. Shown is a box-plot of results of the pathological groups as indicated in hippocampus/entorhinal cortex. The expression levels were normalized to eEF $2 \alpha$ mRNA. Kruskall-Wallis test was used to evaluate differences between groups followed by the Mann-Whitney $\mathrm{U}$ test, to test differences between pairs of groups. doi:10.1371/journal.pone.0044674.g001

\section{QC Expression is not Upregulated by $A \beta$ or the UPR}

Because $\mathrm{QC}$ is increased very early in $\mathrm{AD}$, we investigated if early events occurring in $\mathrm{AD}$ might be involved in the regulation. Therefore differentiated SK-N-SH were treated with increasing concentrations of either oligomeric or fibrillar $A \beta_{1-42}$ for $24 \mathrm{~h}$ and subsequently the expression level of QC mRNA was measured by semi-quantitative real-time PCR analysis (Fig. 2A). Treatment with $A \beta$ did not increase the $Q C$ mRNA level - fibrillar $A \beta_{1-42}$ at $2 \mu \mathrm{M}$ even slightly reduced the QC level - indicating that this is not a signal to increase QC expression.

Previously, our group demonstrated that UPR activation, which is known to affect the expression of several genes, is an early event in Alzheimer's disease brain. Therefore we used different chemical compounds (tunicamycin [TM], thapsigargin [TG] and 2-deoxyd-glucose [DG]), to induce the UPR in the differentiated SK-NSH (Fig. 2B). All treatments increase the levels of the UPRresponsive mRNA $\mathrm{BiP}$, confirming that the UPR is activated. In contrast, the QC mRNA expression level was not increased by

A

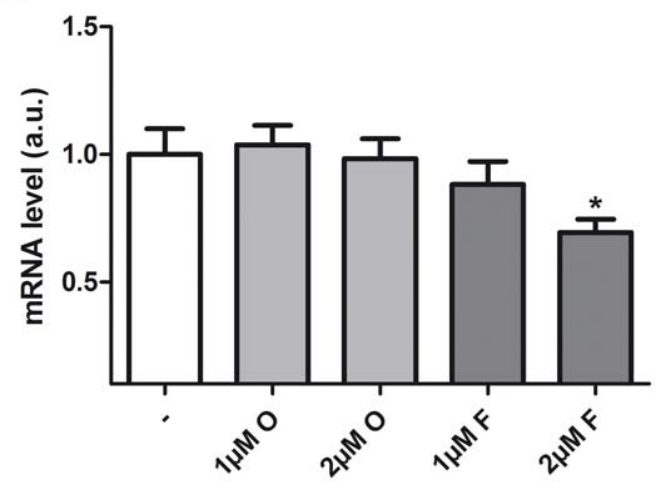

B

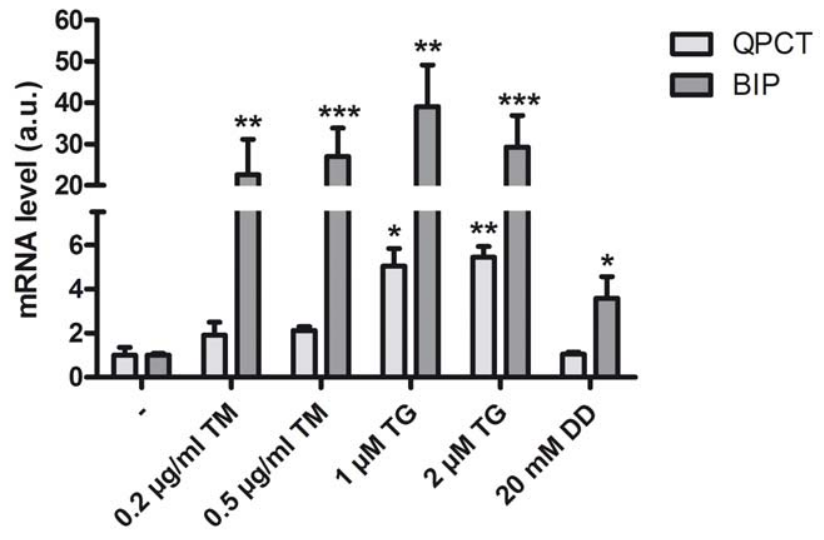

Figure 2. QC expression is not upregulated by $A \beta$ or the UPR. A. Differentiated SK-N-SH cells were treated with $1 \mu \mathrm{M}$ and $2 \mu \mathrm{M}$ oligomeric (O) and fibrillary (F) $A \beta_{1-42}$ for $24 \mathrm{~h}$. Shown is the average $+\mathrm{SD}$ of normalized QC mRNA levels of triplicates from a representative experiment B. Differentiated SK-N-SH cells were treated with different UPR inducers, TM $(0.2 \mu \mathrm{g} / \mu \mathrm{l}$ and $0.5 \mu \mathrm{g} / \mu \mathrm{l}), \mathrm{TG}(1 \mu \mathrm{M}$ and $2 \mu \mathrm{M})$ and DD $(20 \mathrm{mM})$ for $16 \mathrm{~h}$. Shown is the average + SD of normalized QC mRNA levels of $n=9$ from 3 independent experiments. Normalized BiP mRNA levels are shown as positive control for UPR induction $(n=6$ from two independent experiments). The expression levels were normalized to eEF $2 \alpha$ mRNA, the levels in untreated cells are set to 1 . Asterisks indicate a significant difference compared with control $\left({ }^{*} p \leq 0.01,{ }^{* *} p \leq 0.001\right.$, $* * * \mathrm{p} \leq 0.0001$ ).

doi:10.1371/journal.pone.0044674.g002 
TM or DG, but only after treatment with TG indicating that activation of the UPR per se does not regulate QC gene expression.

\section{Disturbed $\mathrm{Ca}^{2+}$ Homeostasis Increases QC Expression and Enzyme Activity}

To further explore the TG induced gene expression of $\mathrm{QC}$, differentiated SK-N-SH cells were treated with increasing concentrations of TG. As shown in Figure 3A a dose-dependent increase in QG mRNA expression levels was observed. The TG induced expression of $\mathrm{QG}$ indicates $\mathrm{Ca}^{2+}$-dependent gene regulation since $\mathrm{TG}$, a specific and irreversible sarco-endoplasmic reticulum ATPase (SERCA) pump inhibitor, blocks the re-uptake of cytosolic $\mathrm{Ca}^{2+}$ into the ER and as a consequence depletes the ER $\mathrm{Ca}^{2+}$ and increases the cytosolic $\mathrm{Ca}^{2+}$ as has been shown by fura-2 $\mathrm{Ca}^{2+}$ imaging [21-24].

To investigate if TG also increased QC activity, we used an enzymatic activity assay. The activity of the enzyme is determined by the ability of QC to convert a glutaminyl residue to a pyroglutamyl residue on a fluorogenic substrate. Differentiated SK-N-SH cells were treated with $1 \mu \mathrm{M}$ TG for $16 \mathrm{~h}$. The

A
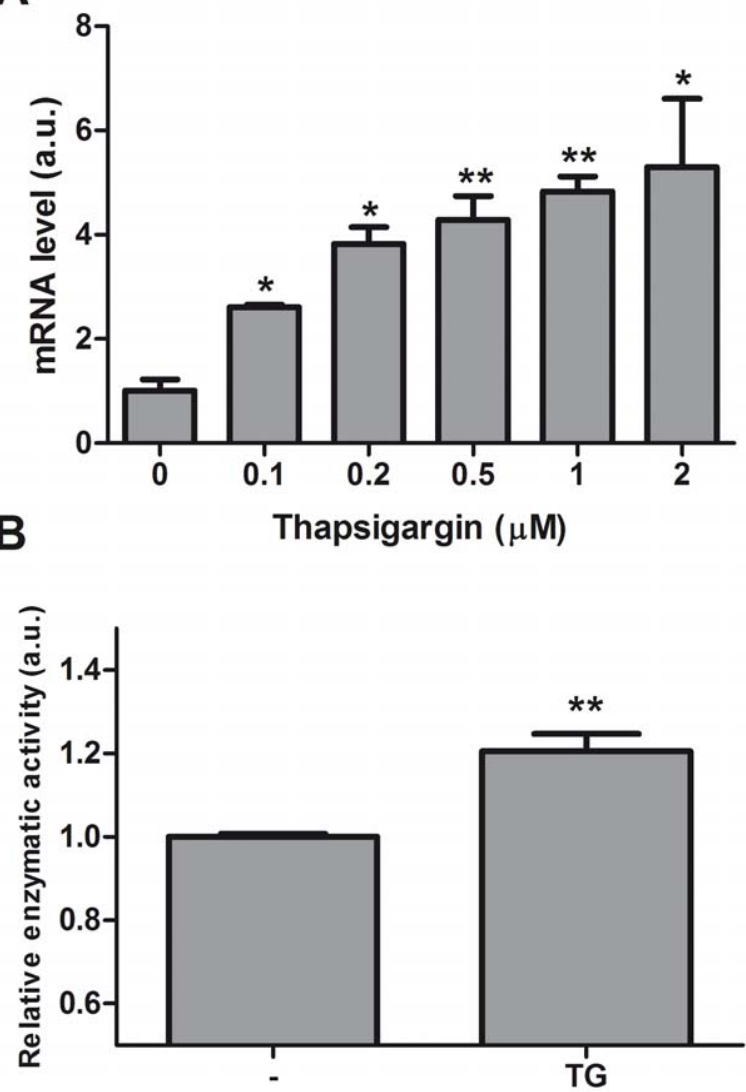

Figure 3. Disturbed $\mathrm{Ca}^{2+}$ homeostasis increases $\mathrm{QC}$ expression and enzyme activity. A. Differentiated SK-N-SH cells were treated with different concentrations TG as indicated. Shown are the average + SD of normalized QC mRNA levels of $n=6$ from two independent experiments. The expression levels were normalized to eEF $2 \alpha$ mRNA, the expression levels in untreated cells are set to 1. B. Differentiated SK$\mathrm{N}$-SH cells were treated with $1 \mu \mathrm{M}$ TG for $16 \mathrm{~h}$. The enzymatic activity of QC activity was determined in protein lysates as described in materials and methods, activity in untreated cells is set to 1 . Shown is average + SEM of $n=15$ from 5 independent experiments. Asterisks indicate a significant difference compared to control $\left({ }^{*} p \leq 0.001,{ }^{* *} p \leq 0.0001\right)$. doi:10.1371/journal.pone.0044674.g003 fluorescence, indicative of the activity of QC, was measured and the data show that treatment with TG induces the fluorescence which is in line with the mRNA expression data (Fig. 3B).

\section{ER $\mathrm{Ca}^{2+}$ Depletion Increases QC Levels}

Conceivably two TG-dependent events could regulate QC mRNA levels (i) TG-mediated $\mathrm{ER} \mathrm{Ca}^{2+}$ pool depletion and/or (ii) TG-initiated rise in cytosolic $\mathrm{Ca}^{2+}$. To investigate which of these two mechanism might be responsible for the TG initiated increase in QC mRNA levels, differentiated SK-N-SH were pretreated $(1 \mathrm{~h})$ with the membrane permeable $\mathrm{Ca}^{2+}$ chelator BAPTA-AM $(5 \mu \mathrm{M})$ before treatment with TG $(16 \mathrm{~h})$ (Fig. 4). Once BAPTAAM enters the cytosol, it is cleaved to membrane-impermeable BAPTA and significantly reduces and maintains a low cytoplasmic $\mathrm{Ca}^{2+}$ concentration even upon subsequent stimulation with TG $[25,26]$. When BAPTA-AM was added separately no increase in QC mRNA expression level was observed. However, the combination of BAPTA and TG strongly potentiated the TG induced QC mRNA expression level (Fig. 4), indicating that it is probably not the rise in the cytosolic $\mathrm{Ca}^{2+}$ but rather the depletion of the $\mathrm{ER} \mathrm{Ca}^{2+}$ that is responsible for the TG induced QC gene expression.

\section{Induction of c-fos and c-jun Precedes Increased QC Expression}

To further analyze the effect of TG on QG expression we determined the expression of $\mathrm{QC}$ at different time points (Fig. 5A). The earliest timepoint where a slight increase is observed is $5 \mathrm{~h}$, but the levels are further increased at $16 \mathrm{~h}$. This relatively slow effect indicates an indirect mechanism, and can be explained if the effect is mediated via the upregulation of a $\mathrm{Ca}^{2+}$-dependent transcription factor.

We used Tfsearch (www.cbrc.jp/research/db/TFSEARCH. html) to identify possible $\mathrm{Ca}^{2+}$-dependent transcription factor binding sites in the proximal promoter region of the $Q C$ gene. The program identified a putative binding site for heterodimers of the transcription factors encoded by the immediate early genes (IEGs) c-fos and c-jun. Disturbed ER $\mathrm{Ca}^{2+}$ homeostasis in neurons leads

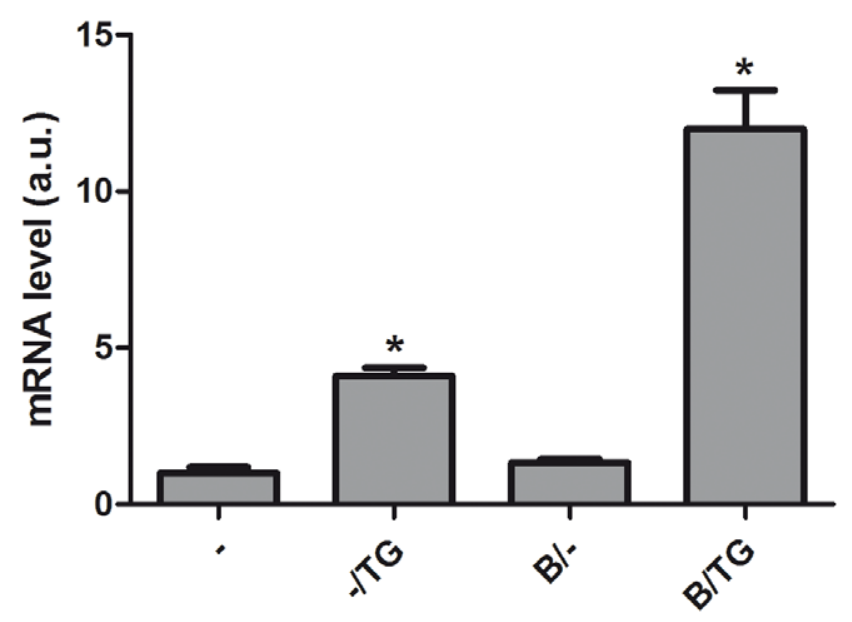

Figure 4. $\mathrm{ER} \mathrm{Ca}^{2+}$ depletion increases QC levels. Differentiated SK$\mathrm{N}$-SH cells were treated with $1 \mu \mathrm{M}$ TG for $16 \mathrm{~h}$ with or without preincubation with $5 \mu \mathrm{M}$ BAPTA-AM (B) for $1 \mathrm{~h}$. Shown are the average + SD of normalized QC mRNA levels of $n=9$ from 3 independent experiments. The expression levels were normalized to eEF2 $\alpha$ mRNA, the expression levels in untreated cells are set to 1 . Asterisks indicate a significant difference compared to control $\left({ }^{*} p \leq 0.0001\right)$. doi:10.1371/journal.pone.0044674.g004 
A
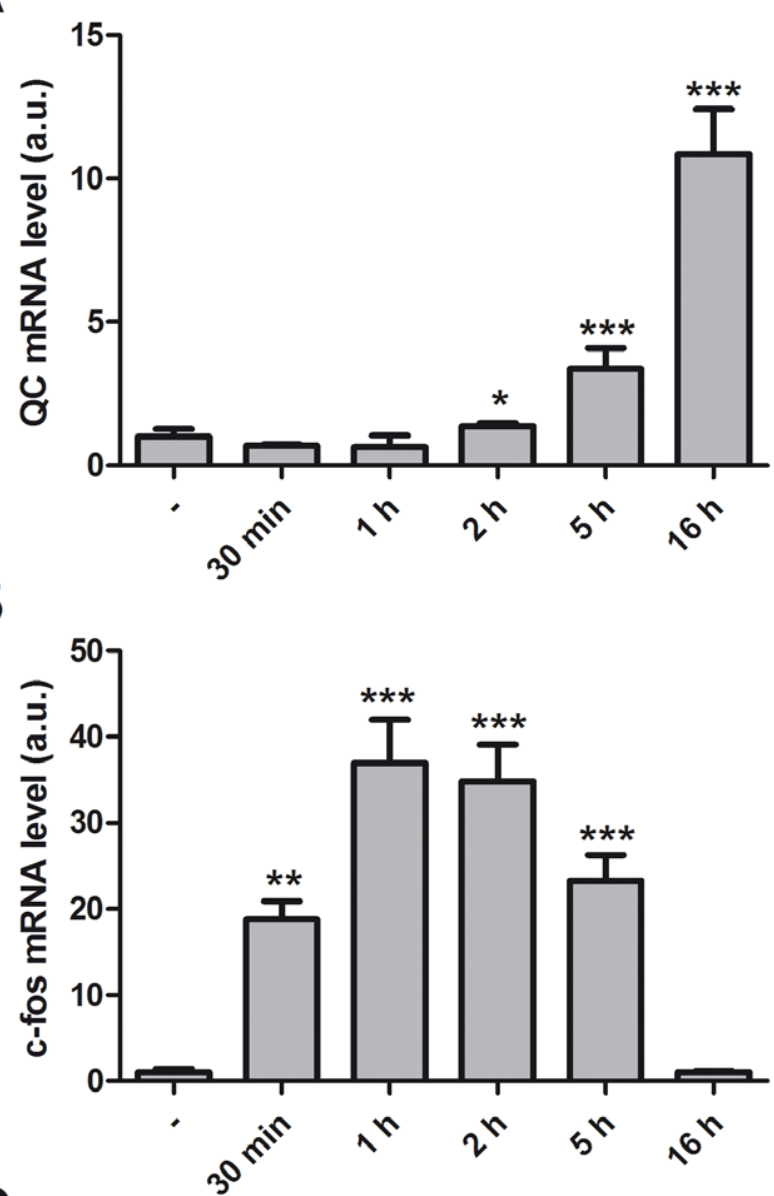

C

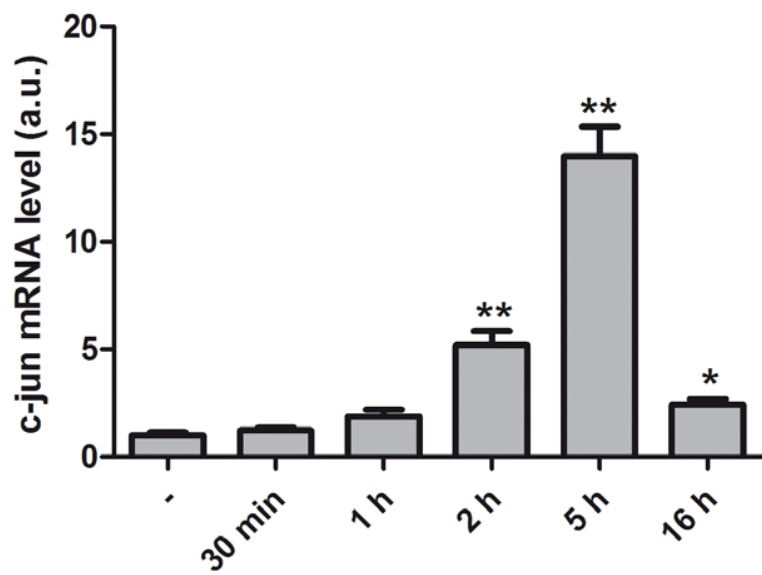

Figure 5. Induction of c-fos and c-jun precedes increased QC expression. Differentiated SK-N-SH cells were treated with $1 \mu \mathrm{M}$ TG for the times indicated. Shown is the average + SD of normalized QC (A), Cfos (B) and c-jun (C) mRNA levels of triplicates from a representative experiment of three. The expression levels were normalized to eEF2 $\alpha$ mRNA, the expression levels in untreated cells are set to 1 . Asterisks indicate a significant difference compared to control ${ }^{*} \mathrm{p}<0.05$; $* * p \leq 0.001 ; * * * p \leq 0.0001)$

doi:10.1371/journal.pone.0044674.g005

to the rapid activation of $\mathrm{c}-\mathrm{fos}$ and c-jun [27]. Therefore we investigated the effect of TG on c-fos and c-jun expression. We found that both IEGs are rapidly induced by $\mathrm{TG}$, c-fos faster than c-jun, but both are high at $5 \mathrm{~h}$ after treatment, whereas after $16 \mathrm{~h}$, both are back to their normal levels (Fig. 5B,C). Like QC, the expression of c-fos by TG is also potentiated by treatment with BAPTA-AM. Again, this effect is observed at $5 \mathrm{~h}$ for c-fos, and at $16 \mathrm{~h}$ for QG (Fig. 6). These data demonstrate that c-fos and c-jun expression precedes QG expression and suggest that the upregulation of QG may involve activation of the QC promoter via c-fos and c-jun.

$\mathrm{Ca}^{2+}$ Induced QC and c-fos mRNA Expression is Neuronal Cell Type Specific

Since $A \beta$ is known to be produced by different cell types in the brain, we investigated which cells express QC. We employed in situ hybridization using LNA probes, to detect the QC mRNA in human temporal cortex and hippocampus/entorhinal cortex. In sequential slides, probes recognizing the QC mRNA and the neuron specific microRNA hsa-mir-134 were used. This demonstrated that QC is predominantly expressed in neurons in different brain areas (Fig. 7A).

To analyze whether the $\mathrm{Ca}^{2+}$-dependent regulation of $\mathrm{QC}$ is cell-type specific, we treated the non-neuronal HEK293 and Hela cell lines with TG. QG is not upregulated by $\mathrm{TG}$ treatment in either cell line (Fig. 7B,C). At 5h, the QC expression is even significantly reduced, but at $16 \mathrm{~h}$ there is no effect of TG observed. Interestingly, also the induction of $\mathrm{c}$-fos by $\mathrm{TG}$ appears to be cell

\section{A}

B
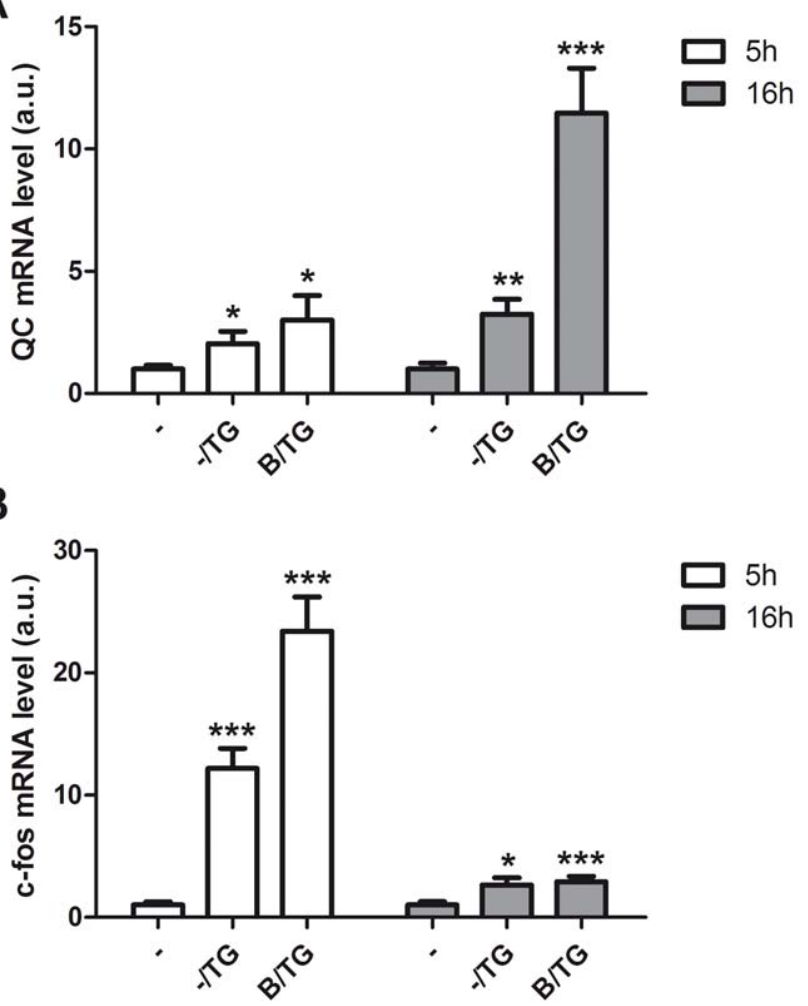

Figure 6. Induction of c-fos by ER $\mathrm{Ca}^{2+}$ depletion precedes QC expression. Differentiated SK-N-SH cells were treated with $1 \mu \mathrm{M}$ TG for $5 \mathrm{~h}$ and $16 \mathrm{~h}$ with or without pre-incubation with $5 \mu \mathrm{M}$ BAPTA-AM (B) for $1 \mathrm{~h}$. Shown are the average + SD of triplicates of normalized QC (A) and $c$-fos (B) mRNA levels from a representative experiment of three. The expression levels were normalized to eEF $2 \alpha$ mRNA, the expression levels in untreated cells are set to 1 . Asterisks indicate a significant difference compared to control $\left({ }^{*} p<0.05,{ }^{* *} p \leq 0.02{ }^{* * *} p \leq 0.001\right)$. doi:10.1371/journal.pone.0044674.g006 
A Temporal cortex

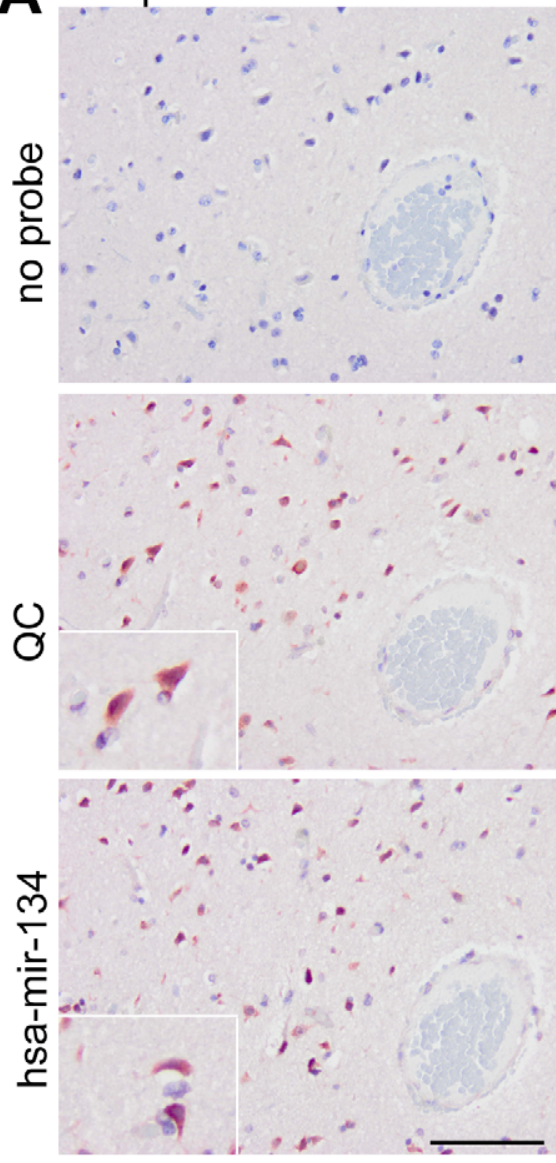

Hippocampus

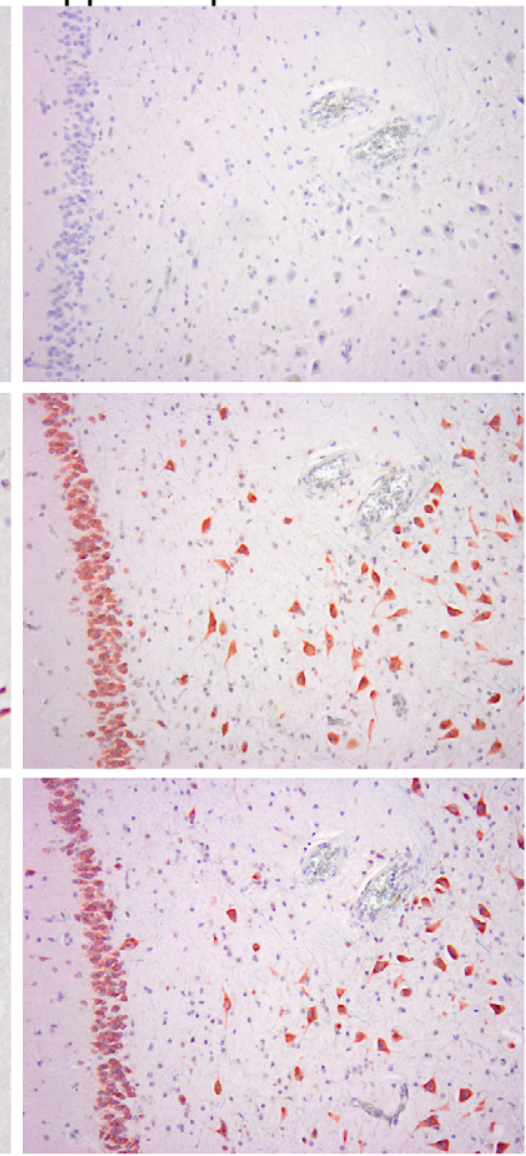

B

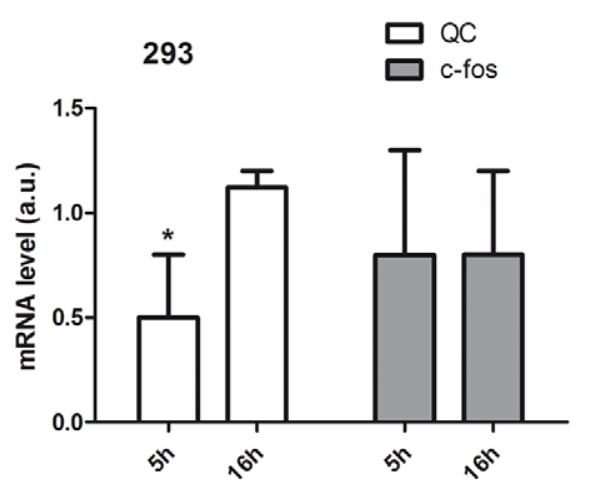

C

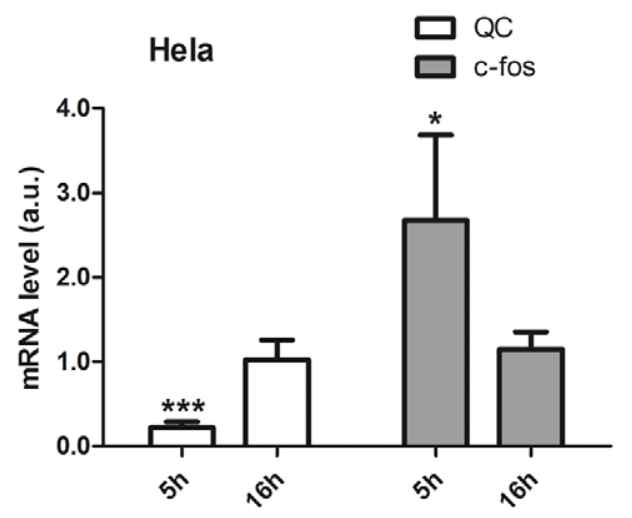

Figure 7. $\mathrm{Ca}^{2+}$ induced QC and c-fos mRNA expression is neuronal cell type specific. A. In situ hybridizations were performed on sequential sections of temporal cortex and hippocampus/entorhinal cortex of a patient with early AD pathology $(\mathrm{I}, \mathrm{B})$ as described in materials and methods. Shown are incubations without probe, using a probe directed against the QC mRNA or a probe recognizing the neuron-specific microRNA hsa-mir134. Scale bar: $100 \mu \mathrm{M}$. B. Hek293 and C. Hela cells were treated with $1 \mu \mathrm{M}$ TG for $5 \mathrm{~h}$ and $16 \mathrm{~h}$. Shown is the average + SD of normalized QC and cfos mRNA levels of $n=6$ from 2 experiments (B) and $n=12$ from 4 experiments (C). The expression levels were normalized to eEF2 $\alpha$ mRNA, the expression levels in untreated cells are set to 1 . Asterisks indicate a significant difference compared to control $\left({ }^{*} \mathrm{p}<0.05,{ }^{* * *} \mathrm{p} \leq 0.0001\right)$. doi:10.1371/journal.pone.0044674.g007

type specific. In the Hela cells the response is much lower than in the SK-N-SH cells and in 293 cells TG does not elicit any effect on the c-fos levels (Fig. 7B,C). These data suggest that the $\mathrm{Ca}^{2+}$ dependent regulation of QC expression is specific for neuronal cells.

\section{Discussion}

The expression of $\mathrm{QC}$, the enzyme that catalyzes the conversion of $\mathrm{A} \beta$ to the more toxic $\mathrm{pE} A \beta$, is upregulated in $\mathrm{AD}$ cortex. Here we demonstrate that also in hippocampus/entorhinal cortex the upregulation of $\mathrm{QC}$ occurs at the earliest stages of $\mathrm{AD}$ pathology. In this study we investigated whether early pathogenic events that occur in $\mathrm{AD}$ brain could be directly involved in this regulation. We demonstrated that QC mRNA expression was not increased by oligomeric or fibrillar A $\beta$ aggregates. Also induction of the UPR, using TM and 2DG was without effect. Only when the UPR was induced by the SERCA pump inhibitor TG the QC mRNA level was increased, indicating the involvement of $\mathrm{Ca}^{2+}$. We tried three different commercially available QC antibodies to directly determine the QC protein levels, but none worked in our hands. Instead we demonstrated that the QG enzyme activity is increased by TG. A $\beta$ has been shown before to affect $\mathrm{Ca}^{2+}$ homeostasis [28], but apparently in a different manner or to a lesser extent than the $\mathrm{Ca}^{2+}$ perturbing stimuli that induce QC expression. $\mathrm{Ca}^{2+}$ signalling plays an important role in the regulation of many processes in cells. In neurons, $\mathrm{Ca}^{2+}$ acts as a second messenger and co-factor for many processes, e.g. neurotransmitter release and long-term potentiation, the cellular mechanism underlying learning and memory [29]. Since $\mathrm{Ca}^{2+}$ is involved in such a broad variety of processes, the $\mathrm{Ca}^{2+}$ signals need to be regulated precisely and this involves regulated changes in $\mathrm{Ca}^{2+}$ concentration in the different cellular compartments. Under resting conditions the cytosolic $\mathrm{Ca}^{2+}$ concentration is kept low by an array of buffers, pumps and transport mechanisms, creating an electro-chemical gradient across the plasma membrane and the intracellular $\mathrm{Ca}^{2+}$ stores, including the ER. $\mathrm{Ca}^{2+}$ is predominantly released from the ER through activation of inositol-1,4,5-triphosphate receptors $\left(\mathrm{IP}_{3} \mathrm{Rs}\right)$ and ryanodine receptors (RyRs), whereas the SERCA pumps refill the store after depletion [30]. Inhibition of SERCA leads to an increase in cytosolic $\mathrm{Ca}^{2+}$ concentration and $\mathrm{ER} \mathrm{Ca}^{2+}$ depletion. Our data show that chelation of intracellular $\mathrm{Ca}^{2+}$ using BAPTA-AM potentiates the QG induction by TG, but does not have an effect by itself. Combined use of TG and BAPTA-AM results in faster and increased release of $\mathrm{Ca}^{2+}$ from the ER. This indicates that depletion of $\mathrm{ER} \mathrm{Ca}^{2+}$ stores is the main trigger to 
increase the expression of QC. To further define the mechanism we analysed the effect of SERCA inhibition in combinations with pharmacological inhibition of the $\mathrm{IP}_{3} \mathrm{Rs}$ and RyRs. Unfortunately these experiments were not informative, probably by artefacts generated by the use of combinations of different pharmacological inhibitors. In addition, it has been shown before that the ER Ca ${ }^{2+}$ leak is not affected by inhibition of the $\mathrm{IP}_{3} \mathrm{Rs}_{\mathrm{s}}$ or of the RyRs [31], probably because of the presence of other $\mathrm{Ca}^{2+}$ leak mediators [32].

Activation of immediate early gene expression is a key event in stress-induced neuronal cell injury [33]. Analysis of the $Q C$ promoter showed the presence of a potential binding site for the heterodimer of the transcription factors c-fos and c-jun, both IEGs. We found that c-fos and c-jun mRNA are induced by the same stimuli as QC mRNA. It was reported before that c-fos is induced in neurons by treatment with TG [27]. Similar to what we report in this study for $\mathrm{QC}$, this increase is caused by $\mathrm{Ca}^{2+}$ depletion of the ER, rather than increased cytosolic $\mathrm{Ca}^{2+}$ levels. The induction of the IEGs is much faster and precedes the upregulation of QC. This is compatible with a model where the upregulation of $\mathrm{QC}$ by $\mathrm{ER} \mathrm{Ca}^{2+}$ depletion is mediated by c-fos and c-jun, although this requires further study. Interestingly, both c-fos and c-jun are upregulated in $\mathrm{AD}$ hippocampus [34].

Using in situ hybridization we demonstrated that $\mathrm{QG}$ is predominantly expressed in neurons in the human brain, both in temporal cortex as well as in the earlier affected area in $\mathrm{AD}$, the hippocampus/entorhinal cortex. The regulation of QC expression by TG appears to be specific for neuronal cells, because it is not observed in non-neuronal cells. Also c-fos is less responsive in nonneuronal cells, which strengthens the hypothesis that IEG induction is required for $\mathrm{Ca}^{2+}$-regulated $\mathrm{QC}$ expression. $\mathrm{BiP}$ is upregulated in response to TG treatment in these cells, indicating that the treatment has resulted in depletion of $\mathrm{ER} \mathrm{Ca}^{2+}$ levels. It is possible that non-neuronal cells have more resources to deal with disturbances in $\mathrm{Ca}^{2+}$ homeostasis, or that neuronal cells are more dependent on proper $\mathrm{Ca}^{2+}$ homeostasis for their function. It has been shown before that a different isoform of $\mathrm{QC}$, isoQC, is involved in monocyte infiltration via modification of cytokines, and therefore it has a major role in cell types involved in the immune response [35]. Our data suggest that QC performs a specific function in neurons. The formation of an N-terminal $\mathrm{pE}$ residue is an important event in the processing of numerous bioactive neuropeptides, hormones and cytokines during their maturation in the secretory pathway $[36,37]$. These peptides need the conformational change to bind to their receptors and/or to protect the $\mathrm{N}$ terminus from degradation. It is possible that $\mathrm{QC}$ is upregulated under stress conditions in neurons to stabilise specific peptides and potentiate their function. Whether the modification of $\mathrm{A} \beta$ is part of this or whether this is a pathological side-effect requires further investigation.

Perturbed $\mathrm{Ca}^{2+}$ homeostasis has been found in both sporadic and in familial (F)AD [38,39]. The majority of cases of FAD originate from a mutant PS gene. In addition to effects on $A \beta$ formation, PS-FAD mutations lead to perturbed neuronal ER $\mathrm{Ca}^{2+}$ signalling $[40,41]$. It was found that PS can function as lowconductance passive ER $\mathrm{Ca}^{2+}$ leak channel and that the FAD mutations disrupt this $\mathrm{Ca}^{2+}$ leak function [42]. This results in higher steady-state intraluminal $\mathrm{Ca}^{2+}$ levels and lower cytosolic $\mathrm{Ca}^{2+}$ homeostasis levels and leads to exaggerated release of $\mathrm{Ca}^{2+}$ from the ER, both in in vitro and in vivo [43,44]. In this respect it is interesting that the intraneuronal levels of $\mathrm{pE} A \beta$ are higher in PS1 FAD patients than in sporadic $\mathrm{AD}$ patients [45]. In sporadic $\mathrm{AD}$, aging is the major risk factor for developing the neurodegenerative disease. The $\mathrm{Ca}^{2+}$ hypothesis of aging emerged two decades ago
[18] and is supported by studies that show age-related alterations in specific $\mathrm{Ca}^{2+}$ homeostasis -regulating systems in neurons $[19,20]$. In the aged brain there is an increased $\mathrm{Ca}^{2+}$ release from the ER stores through both the RyR and the $\mathrm{IP}_{3}$ receptors [46]. Interestingly, our group recently demonstrated that the accumulation of intracellular $\mathrm{pE}$ aggregates in human brain is also highly dependent on age [3]. The data presented here suggest that perturbed ER $\mathrm{Ca}^{2+}$ homeostasis facilitates the production of $\mathrm{pE}$ modified $A \beta$ and may thereby contribute to the amyloid pathology in $\mathrm{AD}$.

\section{Materials and Methods}

\section{Cell Culture and Treatment}

SK-N-SH (European Collection of Cell Cultures \#86012802, Salisbury, UK), 293 and Hela cells were cultured in Dulbecco's modified Eagle's medium with GlutaMAX (Gibco BRL, Carlsbad, CA, USA) supplemented with 10\% fetal calf serum (FCS, Gibco $\mathrm{BRL}), 100 \mu \mathrm{g} / \mathrm{ml}$ streptomycin and $100 \mathrm{U} / \mathrm{ml}$ penicillin. SK-NSH cells were differentiated in culture medium supplemented with all trans-retinoic acid (Sigma, St Louis, MO, USA) at a final concentration of $10 \mu \mathrm{M}$ for 5 days. Differentiated cells were treated with $\mathrm{A} \beta_{1-42}$ oligomers or fibrils, TG, TM, DG (all from Sigma) and BAPTA-AM (Calbiochem, Darmstadt, Germany) at the indicated concentrations and time points.

\section{Preparation of Different $A \beta$ Species}

Synthetic $A \beta_{1-42}$ was purchased from Anaspec (San Jose, CA, USA). A $\beta_{1-42}$ was dissolved in hexafluorisopropanol (HFIP) at a final concentration of $1 \mathrm{mg} / \mathrm{ml}$, aliquoted and dried under vacuum. The resulting peptide film was stored at $-80^{\circ} \mathrm{C}$ until further use. To obtain low molecular weight $\mathrm{A} \beta$, the peptide film was dissolved in DMSO $(5 \mathrm{mM})$, and sonicated in a bath sonicator for 10 minutes. A $\beta$ was subsequently diluted in PBS to a final concentration of $50 \mu \mathrm{M}$. To enrich for oligomers, this mixture was incubated at $4^{\circ} \mathrm{C}$ for $24 \mathrm{~h}$. High order aggregates were removed by centrifugation $(10 \mathrm{~min}, 14000 \mathrm{rpm})$ at $4^{\circ} \mathrm{C}$. To obtain fibrillar $\mathrm{A} \beta$, the peptide film was dissolved in DMSO $(5 \mathrm{mM})$. Then $10 \mathrm{mM} \mathrm{HCl}$ was added to bring the peptide to $100 \mu \mathrm{M}$ concentration and incubated for $24 \mathrm{~h}$ at $37^{\circ} \mathrm{C}$. The final concentration of the oligomeric and the fibrillar A $\beta$ 1-42 preparations was determined using Bradford protein assay and the $\beta$-sheet content was determined by a Thioflavin $\mathrm{T}$ assay.

\section{Post-mortem Brain Tissue}

Post-mortem brain material was obtained from the Netherlands Brain Bank (Amsterdam, The Netherlands). All donors or their next of kin provided written informed consent for brain autopsy and use of tissue and medical records for research purposes. The parameters of all tissue samples used in this study are listed in Table 1.

\section{RNA Isolation and Real-time Quantitative PCR}

Total RNA was isolated from differentiated SK-N-SH cells, untreated or treated, and post-mortem brain tissue with the RNAeasy minikit (Qiagen, Netherlands). cDNA synthesis was performed using Superscript II reverse transcriptase (Invitrogen, Carlsbad, CA) and oligo-dT primers. Real-time quantitative PCR (qPCR) was performed using the Light Cycler 480 system (Roche Applied Science, USA). Reaction volumes of $5 \mu \mathrm{l}$ contained cDNA, 0.1 $\mu \mathrm{M}$ Universal Probe Library probe (Roche Applied Science, USA), $0.4 \mu \mathrm{M}$ forward primer, $0.4 \mu \mathrm{M}$ reverse primer and $2.5 \mu \mathrm{l} 2 \mathrm{x}$ LightCycler 480 Probes Master (Roche Applied Science, USA). After denaturation for $10 \mathrm{~min}$ at $95^{\circ} \mathrm{C}$, amplifi- 
Table 1. Post-mortem brain material used in this study.

\begin{tabular}{|c|c|c|c|c|c|c|}
\hline Case & $\begin{array}{l}\text { Clinical } \\
\text { diagnosis }\end{array}$ & $\begin{array}{l}\text { Braak } \\
\text { stage }\end{array}$ & Gender & Age & $\begin{array}{l}\text { ApoE } \\
\text { genotype }\end{array}$ & PMI \\
\hline 1 & CON & 0 & $M$ & 80 & 33 & $07: 15$ \\
\hline 2 & CON & 2 & $\mathrm{~F}$ & 93 & 33 & 05:50 \\
\hline 3 & CON & 1 & M & 84 & 33 & 07:05 \\
\hline 4 & CON & 2 & $M$ & 87 & 33 & $07: 20$ \\
\hline 5 & CON & 1 & $\mathrm{~F}$ & 83 & 32 & $05: 30$ \\
\hline 6 & CON & 1 & $\mathrm{~F}$ & 81 & 33 & $06: 40$ \\
\hline 7 & CON & 1 & M & 85 & 44 & $04: 15$ \\
\hline 8 & CON & 2 & $\mathrm{~F}$ & 86 & 43 & $06: 25$ \\
\hline 9 & CON & 1 & M & 91 & 33 & 08:00 \\
\hline 10 & CON & 1 & $\mathrm{~F}$ & 85 & 33 & $05: 00$ \\
\hline 11 & $A D$ & 4 & $\mathrm{~F}$ & 94 & 33 & $05: 00$ \\
\hline 12 & CON & 3 & $\mathrm{~F}$ & 91 & 32 & $05: 20$ \\
\hline 13 & $A D$ & 3 & $M$ & 86 & 43 & $05: 35$ \\
\hline 14 & CON & 3 & $M$ & 74 & 43 & $05: 00$ \\
\hline 15 & $A D$ & 4 & $\mathrm{~F}$ & 86 & 43 & 05:55 \\
\hline 16 & $A D$ & 4 & $\mathrm{~F}$ & 84 & 43 & $04: 50$ \\
\hline 17 & $A D$ & 5 & $\mathrm{~F}$ & 89 & 33 & $10: 20$ \\
\hline 18 & $A D$ & 6 & $\mathrm{~F}$ & 81 & 33 & $06: 00$ \\
\hline 19 & $A D$ & 6 & M & 69 & 43 & 05:00 \\
\hline 20 & $A D$ & 6 & $\mathrm{~F}$ & 67 & 32 & 06:05 \\
\hline 21 & $A D$ & 5 & $M$ & 75 & 43 & $05: 25$ \\
\hline 22 & $A D$ & 5 & $\mathrm{~F}$ & 94 & 33 & $04: 30$ \\
\hline 23 & $A D$ & 6 & $\mathrm{~F}$ & 91 & 43 & $05: 45$ \\
\hline
\end{tabular}

Listed are clinical diagnosis $(\mathrm{CON}=$ control, $A D=$ Alzheimer's disease), Braak stage, gender, age (in years), ApoE genotype, post-mortem interval (PMI, in hours: minutes).

doi:10.1371/journal.pone.0044674.t001

cation was performed using 35 cycles of denaturation $\left(95^{\circ} \mathrm{C}\right.$ for $10 \mathrm{~s})$, followed by annealing $\left(58^{\circ} \mathrm{C}\right.$ for $\left.15 \mathrm{~s}\right)$, and elongation $\left(72^{\circ} \mathrm{C}\right.$ for $15 \mathrm{~s}$ ). Results were analysed using the LightCycler 480 software (Roche Applied Science, USA) version 1.5. Expression levels were normalized using eEF2 $\alpha$. Primers and probes used in this study are listed in Table 2.

\section{Activity Assay}

Cells were washed with PBS and lysed in PBS+1\%Triton. Subsequently the supernatant was collected after centrifugation $12000 \times \mathrm{g}$ at $4^{\circ} \mathrm{C}$ for 10 minutes. The protein concentration was determined by the Bradford Assay (Bio-Rad, Laboratories, Veenendaal, The Netherlands). $100 \mu \mathrm{l}$ lysate $(0.5 \mathrm{mg} / \mathrm{ml})$ was mixed with $100 \mu \mathrm{l}$ of $200 \mu \mathrm{M}$ Q-AMC (Bachem, The Netherlands) in assay buffer (25 mM HEPES, $\mathrm{pH} 7.0$ ) and incubated in dark tubes at room temperature for 20 minutes. The reaction was stopped at $100^{\circ} \mathrm{C}$ for 5 minutes and the incubations were cooled on ice for 3 minutes. Subsequently $200 \mu \mathrm{l}$ of rhPGPEP-1 (0.1 $\mu \mathrm{g}$ / ml, 6278-CY, R\&D systems, Europe) was added to each vial and the mixture was incubated at room temperature for 10 minutes. Fluorescence was measured using a FLUOstar Omega (BMG LABTECH GmbH, Ortenberg, Germany).

\section{In situ Hybridization}

In situ hybridization was essentially performed as described before [47]. For human QC a 5' fluorescein labeled 19mer antisense oligonucleotide was used, containing Locked Nucleic Acid (LNA) and 2'OME RNA moieties (FAM - AuuTucTucAuuGucAucC, capitals indicate LNA, lower case indicates 2'OME RNA). An antisense oligo targeting the neuron-specific hsa-miR-134 was used (FAM - CucTggTcaAccAguCacA) to detect neurons and as negative control an oligo that does not detect a signal in human brain (FAM - TaaCccTaaGgcAauTccT). The oligonucleotides were synthesized by Ribotask ApS, Odense, Denmark. The hybridizations were done on $5 \mu \mathrm{M}$ sections of paraffin embedded temporal cortex material obtained from the Netherland Brain Bank. In brief, sections were deparaffinized, treated with proteinase $\mathrm{K}(20 \mu \mathrm{g} / \mathrm{ml})$ for $5 \mathrm{~min}$. Hybridizations were done at $60^{\circ} \mathrm{C}$ for $90 \mathrm{~min}$ in hybridization mix $(50 \%$ (vol/vol) deionized formamide, $600 \mathrm{mM} \mathrm{NaCl}, 10 \mathrm{mM}$ HEPES buffer, pH 7.5, $1 \mathrm{mM}$ EDTA, $5 \times$ Denhardt's reagent and $200 \mu \mathrm{g} / \mathrm{ml}$ denatured herring sperm DNA). The oligonucleotide concentration in the hybridization mix was $1 \mu \mathrm{M}$. The $\mathrm{QC}$ incubations were also performed at lower concentration $(0.25 \mu \mathrm{M})$ with similar result. After hybridization the tissue sections were washed consecutively for 5 min with $2 \times \mathrm{SSC}, 0.5 \times \mathrm{SSC}$ and $0.2 \times \mathrm{SSC}$ at $60^{\circ} \mathrm{G}$. The hybridization signal was detected using a rabbit polyclonal $\alpha$-fluorescein/Oregon green antibody (Molecular Probes) and a horse radish peroxidase (HRP) labeled goat $\alpha$ rabbit polyclonal antibody as secondary antibody. Signal was detected with standard 3-amino-9-ethylcarbazole staining (AEC) and hematoxylin was used as a nuclear counterstain.

Table 2. Primers and probes used for $q P C R \quad 480$ light cycler.

\begin{tabular}{|c|c|c|c|}
\hline Gene & Primers & Product size (bp) & Probe no. \\
\hline QC & $\begin{array}{l}\text { Fw: TGC AAA GAT GGC ATC GAC } \\
\text { Rev: CCA ATC AAA TCC AAT AAG ACC AA }\end{array}$ & 93 & \#1 \\
\hline c-Fos & $\begin{array}{l}\text { Fw: CTA CCA CTC ACC CGC AGA CT } \\
\text { Rev: AGG TCC GTG CAG AAG TCC T }\end{array}$ & 72 & \#67 \\
\hline c-Jun & $\begin{array}{l}\text { Fw: CCA AAG GAT AGT GCG ATG TाT } \\
\text { Rev: CTG TCC CTC TCC ACT GCA AC }\end{array}$ & 62 & \#19 \\
\hline BiP & $\begin{array}{l}\text { Fw: GCT GGC CTA AAT GTT ATG AGG A } \\
\text { Rev: CCA CCC AGG TCA AAC ACC }\end{array}$ & 110 & \#7 \\
\hline Eef $2 \alpha$ & $\begin{array}{l}\text { Fw: CAA TGG CAA AAT CTC ACT GC } \\
\text { Rev: AAC CTC ATC TCT ATT AAA AAC ACC AAA }\end{array}$ & 122 & \#63 \\
\hline
\end{tabular}

Probe numbers refer to numbers in the Roche universal probe library.

doi:10.1371/journal.pone.0044674.t002 


\section{Acknowledgments}

We thank Kees Fluiter for help with the in situ hybridization.

\section{References}

1. De Kimpe L, Scheper W (2010) From alpha to omega with $A \beta$ : targeting the multiple molecular appearances of the pathogenic peptide in Alzheimer's disease. Curr Med Chem 17: 198-212.

2. Schilling S, Wasternack C, Demuth HU (2008) Glutaminyl cyclases from animals and plants: a case of functionally convergent protein evolution. Biol Chem 389: 983-991.

3. De Kimpe L., Van Haastert ES, Kaminari A, Zwart R, Rutjes H, et al. (2012) Intracellular accumulation of aggregated pyroglutamate amyloid beta: convergence of aging and A $\beta$ pathology at the lysosome. AGE 10.1007/s11357-0129403-0 [doi].

4. He W, Barrow CJ (1999) The A $\beta$ 3-pyroglutamyl and 11-pyroglutamyl peptides found in senile plaque have greater beta-sheet forming and aggregation propensities in vitro than full-length A $\beta$. Biochemistry 38: 10871-10877.

5. Schlenzig D, Manhart S, Cinar Y, Kleinschmidt M, Hause G, et al. (2009) Pyroglutamate formation influences solubility and amyloidogenicity of amyloid peptides. Biochemistry 48: 7072-7078.

6. Schilling S, Lauber T, Schaupp M, Manhart S, Scheel E, et al. (2006) On the seeding and oligomerization of pGlu-amyloid peptides (in vitro). Biochemistry 45: 12393-9.

7. Saido TC, Iwatsubo T, Mann DM, Shimada H, Ihara Y, et al. (1995) Dominant and differential deposition of distinct beta-amyloid peptide species, A beta $\mathrm{N} 3(\mathrm{pE})$, in senile plaques. Neuron 14: 457-466.

8. Mori H, Takio K, Ogawara M, Selkoe DJ (1992) Mass spectrometry of purified amyloid beta protein in Alzheimer's disease. J Biol Chem 267: 17082-17086.

9. Schilling S, Hoffmann T, Manhart S, Hoffmann M, Demuth HU (2004) Glutaminyl cyclases unfold glutamyl cyclase activity under mild acid conditions. FEBS Lett 563: 191-196.

10. Cynis H, Scheel E, Saido TC, Schilling S, Demuth HU (2008) Amyloidogenic processing of amyloid precursor protein: evidence of a pivotal role of glutaminyl cyclase in generation of pyroglutamate-modified amyloid-beta. Biochemistry 47 : 7405-7413.

11. Jawhar S, Wirths O, Schilling S, Graubner S, Demuth HU, et al. (2011) Overexpression of glutaminyl cyclase, the enzyme responsible for pyroglutamate $\mathrm{A} \beta$ formation, induces behavioral deficits, and glutaminyl cyclase knock-out rescues the behavioral phenotype in 5XFAD mice. J Biol Chem 286: 4454 4460 .

12. Schilling S, Zeitschel U, Hoffmann T, Heiser U, Francke M, et al. (2008) Glutaminyl cyclase inhibition attenuates pyroglutamate Abeta and Alzheimer's disease-like pathology. Nat Med 14: 1106-1111.

13. Hoozemans JJ, Veerhuis R, Van Haastert ES, Rozemuller JM, Baas F, et al. (2005) The unfolded protein response is activated in Alzheimer's disease. Acta Neuropathol (Berl) 110: 165-172.

14. Hoozemans JJM, Van Haastert ES, Nijholt DAT, Rozemuller AJM, Eikelenboom P, et al. (2009) The Unfolded Protein Response is activated in pretangle neurons in Alzheimer's disease hippocampus. Am J Pathol 174: 12411251 .

15. Chafekar SM, Zwart R, Veerhuis R, Vanderstichele H, Baas F, et al. (2008) Increased Abeta 1-42 production sensitizes neuroblastoma cells for ER stress toxicity. Curr Alzheimer Res 5: 469-74.

16. Chafekar SM, Hoozemans JJ, Zwart R, Eikelenboom P, Baas F, et al. (2007) Abeta1-42 induces mild endoplasmic reticulum stress in an aggregation state dependent manner. Antioxid Redox Signal 9: 2245-54.

17. Emilsson L, Saetre P, Jazin E (2006) Alzheimer's disease: mRNA expression profiles of multiple patients show alterations of genes involved with calcium signaling. Neurobiol Dis 21: 618-625.

18. Khachaturian ZS (1987) Hypothesis on the regulation of cytosol calcium concentration and the aging brain. Neurobiol Aging 8: 345-346.

19. Mattson MP, Magnus T (2006) Ageing and neuronal vulnerability. Nat Rev Neurosci 7: 278-294.

20. Murchison D, Griffith WH (2007) Calcium buffering systems and calcium signaling in aged rat basal forebrain neurons. Aging Cell 6: 297-305.

21. Chung KC, Sung JY, Ahn W, Rhim H, Oh TH, et al. (2001) Intracellular calcium mobilization induces immediate early gene pip92 via Src and mitogenactivated protein kinase in immortalized hippocampal cells. J Biol Chem 276: 2132-2138.

22. Gruszczynska-Biegala J, Pomorski P, Wisniewska MB, Kuznicki J (2011) Differential roles for STIM1 and STIM2 in store-operated calcium entry in rat neurons. PLoS One 6: e19285. 10.1371/journal.pone.0019285 [doi].

\section{Author Contributions}

Conceived and designed the experiments: LDK WS. Performed the experiments: LDK AB RZ EvS. Analyzed the data: LDK AB RZ EvS JJMH WS. Wrote the paper: LDK WS.

23. Moore WC, Hargrove HM, Salama AI, Patel J (1991) Calcium mobilization and entry by thapsigargin in neuronal tumor cell line, SK-N-SH. Neuroreport 2: $124-126$.

24. Weber JT, Rzigalinski BA, Ellis EF (2001) Traumatic injury of cortical neurons causes changes in intracellular calcium stores and capacitative calcium influx. J Biol Chem 276: 1800-1807.

25. Muallem S, Khademazad M, Sachs G (1990) The route of Ca2+ entry during reloading of the intracellular $\mathrm{Ca} 2+$ pool in pancreatic acini. J Biol Chem 265: 2011-2016.

26. Preston SF, Berlin RD (1992) An intracellular calcium store regulates protein synthesis in HeLa cells, but it is not the hormone-sensitive store. Cell Calcium 13: 303-312.

27. Gissel C, Doutheil J, Paschen W (1997) Temporal analysis of changes in neuronal c-fos mRNA levels induced by depletion of endoplasmic reticulum calcium stores: effect of clamping cytoplasmic calcium activity at resting levels. J Neurochem 69: 2538-2545.

28. Demuro A, Parker I, Stutzmann GE (2010) Calcium signaling and amyloid toxicity in Alzheimer disease. J Biol Chem 285: 12463-12468.

29. Berridge MJ, Bootman MD, Lipp P (1998) Calcium-a life and death signal. Nature 395: 645-648.

30. Stutzmann GE, Mattson MP (2011) Endoplasmic reticulum $\mathrm{Ca}(2+)$ handling in excitable cells in health and disease. Pharmacol Rev 63: 700-727.

31. Hofer AM, Curci S, Machen TE, Schulz I (1996) ATP regulates calcium leak from agonist-sensitive internal calcium stores. FASEB J 10: 302-308.

32. Camello C, Lomax R, Petersen OH, Tepikin AV (2002) Calcium leak from intracellular stores-the enigma of calcium signalling. Cell Calcium 32: 355-361.

33. Herrera DG, Robertson HA (1996) Activation of c-fos in the brain. Prog Neurobiol 50: 83-107.

34. Sajan FD, Martiniuk F, Marcus DL, Frey WH, Hite R, et al. (2007) Apoptotic gene expression in Alzheimer's disease hippocampal tissue. Am J Alzheimers Dis Other Demen 22: 319-328.

35. Cynis H, Hoffmann T, Friedrich D, Kehlen A, Gans K, et al. (2011) The isoenzyme of glutaminyl cyclase is an important regulator of monocyte infiltration under inflammatory conditions. EMBO Mol Med 3: 545-558.

36. Hinke SA, Pospisilik JA, Demuth HU, Mannhart S, Kuhn-Wache K, et al. (2000) Dipeptidyl peptidase IV (DPIV/CD26) degradation of glucagon. Characterization of glucagon degradation products and DPIV-resistant analogs. J Biol Chem 275: 3827-3834.

37. Van CE, Proost P, Van A, I, Struyf S, Polfliet M, et al. (1998) Functional comparison of two human monocyte chemotactic protein-2 isoforms, role of the amino-terminal pyroglutamic acid and processing by CD26/dipeptidyl peptidase IV. Biochemistry 37: 12672-12680.

38. Toescu EC, Vreugdenhil M (2010) Calcium and normal brain ageing. Cell Calcium 47: 158-164.

39. Supnet G, Bezprozvanny I (2011) Presenilins function in ER calcium leak and Alzheimer's disease pathogenesis. Cell Calcium 50: 303-309.

40. Supnet C, Bezprozvanny I (2010) The dysregulation of intracellular calcium in Alzheimer disease. Cell Calcium 47: 183-189.

41. Demuro A, Parker I, Stutzmann GE (2010) Calcium signaling and amyloid toxicity in Alzheimer disease. J Biol Chem 285: 12463-12468.

42. Tu H, Nelson O, Bezprozvanny A, Wang Z, Lee SF, et al. (2006) Presenilins form ER Ca2+ leak channels, a function disrupted by familial Alzheimer's disease-linked mutations. Cell 126: 981-993.

43. Bezprozvanny I, Mattson MP (2008) Neuronal calcium mishandling and the pathogenesis of Alzheimer's disease. Trends Neurosci 31: 454-463.

44. Smith IF, Green KN, LaFerla FM (2005) Calcium dysregulation in Alzheimer's disease: recent advances gained from genetically modified animals. Cell Calcium 38: 427-437.

45. Wirths O, Erck C, Martens H, Harmeier A, Geumann C, et al. (2010) Identification of low molecular weight pyroglutamate $A \beta$ oligomers in Alzheimer disease: a novel tool for therapy and diagnosis. J Biol Chem 285: 41517-41524.

46. Thibault O, Gant JC, Landfield PW (2007) Expansion of the calcium hypothesis of brain aging and Alzheimer's disease: minding the store. Aging Cell 6: 307317.

47. Budde BS, Namavar Y, Barth PG, Poll-The BT, Nurnberg G, et al. (2008) tRNA splicing endonuclease mutations cause pontocerebellar hypoplasia. Nat Genet 40: 1113-1118. 